\title{
Author Correction: Genomic profile of advanced breast cancer in circulating tumor DNA
}

Belinda Kingston (1), Rosalind J. Cutts, Hannah Bye, Matthew Beaney, Giselle Walsh-Crestani, Sarah Hrebien,

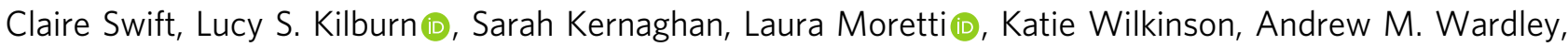
lain R. Macpherson (1), Richard D. Baird (1), Rebecca Roylance, Jorge S. Reis-Filho (D, Michael Hubank, Iris Faull (D), Kimberly C. Banks (D), Richard B. Lanman (D), Isaac Garcia-Murillas (D, Judith M. Bliss, Alistair Ring (1) \& Nicholas C. Turner

Correction to: Nature Communications https://doi.org/10.1038/s41467-021-22605-2, published online 23 April 2021.

The original version of this Article contained an error in Fig. 4. In Fig. 4b the asterisks denoting significance were incorrectly shown as red instead of black. This error has been corrected in the PDF and HTML versions of the Article.

Published online: 16 July 2021

(c) Open Access This article is licensed under a Creative Commons Attribution 4.0 International License, which permits use, sharing, adaptation, distribution and reproduction in any medium or format, as long as you give appropriate credit to the original author(s) and the source, provide a link to the Creative Commons license, and indicate if changes were made. The images or other third party material in this article are included in the article's Creative Commons license, unless indicated otherwise in a credit line to the material. If material is not included in the article's Creative Commons license and your intended use is not permitted by statutory regulation or exceeds the permitted use, you will need to obtain permission directly from the copyright holder. To view a copy of this license, visit http://creativecommons.org/licenses/by/4.0/.

(C) The Author(s) 2021 